\title{
A PRODUCTION OF BIOGAZ IS ON WASTES OF ALCOHOL INDUSTRY OF UKRAINE
}

\author{
Dr. of economics Samborska Oksana, assistant Zubar Ivan \\ Ukraine, Vinnytsia, Vinnytsia national agrarian university
}

DOI: https://doi.org/10.31435/rsglobal_ws/31102019/6724

\section{ARTICLE INFO}

Received: 28 August 2019

Accepted: 12 October 2019

Published: 31 October 2019

\begin{abstract}
Effective utilization of wastes of an alcohol industry is investigational in bioenergetics with the aim of reduction to energy dependence of enterprises, providing of power autonomy of subjects of menage, increase of economic efficiency, improvement of ecological situation.
\end{abstract}

\section{KEYWORDS}

biogaz, wastes, energy,

efficiency, biomass.

Citation: Samborska Oksana, Zubar Ivan. (2019) A Production of Biogaz is on Wastes of Alcohol Industry of Ukraine. World Science. 10(50), Vol.2. doi: 10.31435/rsglobal_ws/31102019/6724

Copyright: (C) 2019 Samborska Oksana, Zubar Ivan. This is an open-access article distributed under the terms of the Creative Commons Attribution License (CC BY). The use, distribution or reproduction in other forums is permitted, provided the original author(s) or licensor are credited and that the original publication in this journal is cited, in accordance with accepted academic practice. No use, distribution or reproduction is permitted which does not comply with these terms.

Introduction. Ukraine is a leader in Europe after the amount of wastes. The indexes of piling up of wastes testify to the threatening ecological situation in a country. Utilization of wastes in power aims will give an opportunity to decide an ecological problem and increase part of biogaz in a general energy consumption. Substituting of traditional fuel by the use of biogaz due to wastes of an alcohol industry, will give an opportunity to the enterprises to decrease the charges on power mediums - $20 \%$ using of fuel and energy resources on $9 \%$. Results of our researches testify that a production of such type of fuel is contradictory: high cost of the use of technique and technologies, receipt of ecological and economic consequences of the use of resources of biomass. Thus, the production of biogaz on the basis of processing of post-alcohol bard waste obtained as a result of economic activity of enterprises of the alcohol industry of Ukraine becomes relevant.

Research results. One of the important sectors of renewable energy in the world is the production and use of biogaz. A biogaz it gas that ensues methane fermentation of biomass. Decomposition of biomass takes place under act of three types of bacteria: the first kind - bacteria are hydrolized; second kind - the bacteria of acid forming; the third kind is bacteria of methanogen class.

Not only methanogen class bacteria are involved in biogaz production, but all three species are listed above. This type of gas consists of methane, its content is 55-70\%, and carbon dioxide content of 45$30 \%$, also contains other inclusions that are released in the biogaz station. By its properties, biogaz is closest to natural gas, accounting for 80-98\% methane, it has no color or odor. Biogaz can be used for incineration in boilers and internal combustion engines without enrichment table 1 . The most common use of biogaz is electricity and heat production. Biogaz is purified by water from $\mathrm{CO}_{2}$ (carbon dioxide), and is brought to the properties of natural gas, such enriched gas is called biomethane.

Table 1. Basic characteristics of biogaz

\begin{tabular}{|l|c|}
\hline \multicolumn{1}{|c|}{ Characteristics } & Indicators \\
\hline energy reserve in $1 \mathrm{~m}^{3}$ of biogaz & $6-6,5 \mathrm{KW}$ \\
\hline calorific value & $4500-6300 \mathrm{kcal} / \mathrm{m}^{3}$ \\
\hline biogaz density & $1,16-1,27 \mathrm{~kg} / \mathrm{m}^{3}$ \\
\hline combustion temperature & $650-750^{\circ} \mathrm{C}$ \\
\hline biogaz pressure in the reactor & $0,05 \mathrm{ATM}$ \\
\hline pressure of biogaz before consumption & rises to the specific \\
\hline
\end{tabular}


Biogaz production will reduce methane emissions into the atmosphere, which has a greenhouse effect of 21 times stronger than $\mathrm{CO}_{2}$ in the atmosphere for 12 years. Reducing methane emissions will help prevent global warming and environmental catastrophe. Recycled manure, after alcohol bard (due to drying) is used as a fertilizer for farmland, which will reduce the use of chemical fertilizers, load on groundwater.

Biogaz plants can be used as treatment facilities on farms, poultry farms, alcohol, sugar factories, meat processing plants. Alcohol processing plants produce a post-alcohol bard that contains virtually all components of the feedstock except starch. In recent years, a large number of post-alcohol bards have not been used in any way, leading to contamination of surrounding areas. In addition, because of the rise in price of fuel, transportation of liquid bards (with a solids content of $5.5-7.0 \%$ ) over long distances is not profitable.

There are 41 of alcohol industry in Ukraine, which produce about 4 million $\mathrm{m}^{3}$ of molasses and 3.6-3.8 million $\mathrm{m}^{3}$ of grain bards per year, and about 8 million $\mathrm{m}^{3}$ of contaminated wastewater. The molasses bard at most plants is not recovered and without treatment, together with sewage, gets to the sump where it decays, polluting the ground water, air. It should be noted that the most favorable conditions for the organization of biogaz production at alcohol factories are: availability of raw materials (wastes) with the required temperature of $40-50^{\circ} \mathrm{C}$, as well as secondary sources of heat (condensates, Luther water). This contributes to the organization of biogaz production at no unnecessary cost, the bioenergy fuel produced to heat the environment in methane tanks.

As a result of the activity of 2017, Ukraine alcohol managed to increase the volume of commodity products. Thus, this figure amounted to UAH 1,964 million, which is UAH 141.6 million or 7.8\% higher than in 2016, which amounted to UAH 1,822.4 million. According to the results 1st quarter of 2018, the volume of commodity products at current prices amounted to UAH 369 million. In 2017, ethyl alcohol was sold in the amount of 7444 thousand decalitres. During the 12 months of 2017, 546.5 thousand dal. of alcohol were shipped for export against 317.9 thousand dal given in 2016. In 2017, the enterprise received tax profit of UAH 15,963 million [8]. During the 1st quarter of 2018, ethyl alcohol was shipped - 1472.44 thousand dollars, including 136.02 thousand gave for export or $10.8 \%$. UAH 65 million invested in modernization of bioethanol production and import substitution for the perfume industry. The total production capacity of Ukraine alcohol is over 36 million decaliters per year [7]. The capacity of the company, as well as the presence of waste after the production of the main product allows the use of new generation biogaz plants.

Table 2. Biogaz output from various raw materials

\begin{tabular}{|c|l|c|}
\hline № & \multicolumn{1}{|c|}{ The name of the raw material } & Indicator $\mathrm{m}^{3} /$ tons \\
\hline 1 & Grain bard (93\% wet) & 40 \\
\hline 2 & Production of alcohol, dal. & 7444000 \\
\hline 3 & The output of the bards liter/1 dal. & 115 \\
\hline 4 & Total output of the bards, liter & 856,06 \\
\hline 5 & Biogaz output 1 tons $/ \mathrm{m}^{3}$ & 40 \\
\hline 6 & Potential for post-alcohol bard biogaz production, thousands $/ \mathrm{m}^{3}$ & 34242,4 \\
\hline
\end{tabular}

We assume the average value of the output of the post-alcohol bard for 115 dal. at 1 dal. alcohol. Such highly concentrated wastewater is characterized by a high content of organic contaminants contained in the dissolved and undissolved state, the chemical oxygen demand (COD) and biochemical oxygen consumption (BOD) reach 40-150 g/dm ${ }^{3}$ and $20-90 \mathrm{~g} / \mathrm{dm}^{3}$, respectively. The creation of combined systems for the processing of waste data into biogaz with its further combustion would significantly improve the economic, environmental performance of alcohol production. Chemical composition of biogaz produced during methane digestion at alcohol plants table 3 .

Table 3. Comparative characteristics of natural gas and biogaz

\begin{tabular}{|l|c|c|}
\hline \multicolumn{1}{|c|}{ Kind of gas } & Natural gas & Biogaz \\
\hline $\mathrm{CH}_{4}$ - methane & $98,9 \%$ & $69,3 \%$ \\
\hline $\mathrm{CO}_{2}$ - carbon dioxide & $0,06 \%$ & $30,2 \%$ \\
\hline $\mathrm{N} 20$ - nitrogen & 0,9 & $0,2 \%$ \\
\hline $\mathrm{O} 2$ - oxygen & 0 & 0,3 \\
\hline $\mathrm{C} 2 \mathrm{H} 6$ - ethane & 0,12 & 0 \\
\hline $\mathrm{C} 3 \mathrm{H} 8$ - propane & 0,01 & 0 \\
\hline $\mathrm{C} 4 \mathrm{H} 10$ - butane & 0,01 & 0 \\
\hline heat combustion, $\mathrm{kJ} / \mathrm{m}^{3}$ & 35503 & 24890 \\
\hline
\end{tabular}


The main gas in alcohol production is natural gas with this composition. The gas we replace is a mixture of biogaz and natural gas. If all biogaz is burned in one plant, it will be necessary to burn $0.096 \mathrm{~m}^{3} / \mathrm{sec}$. of biogaz and $0.1697 \mathrm{~m}^{3} / \mathrm{sec}$. of natural gas to provide the required burner heat capacity. The share of biogaz in the mixture is 0.361 the share of natural gas is 0.639 . The mixture of gases in this case will have the following chemical composition: $\mathrm{CH} 4 \mathrm{~cm}=88,21 \% ; \mathrm{C} 2 \mathrm{H6cm}=0.077 \%$; $\mathrm{C} 3 \mathrm{H} 8 \mathrm{~cm}=0.00639 \% ; \mathrm{C} 4 \mathrm{H} 10 \mathrm{~cm}=0.00639 \% ; \mathrm{CO}_{2} \mathrm{~cm}=10.94 \% ; \mathrm{N} 2 \mathrm{~cm}=0.6473 \% ; \mathrm{O}_{2} \mathrm{~cm}=$ $0.1083 \%$, combustion heat $\mathrm{Q}=31641.7 \mathrm{~kJ} / \mathrm{m}^{3}$.

Estimation of greenhouse gas emission reductions in electricity and heat production (through the use of biogaz instead of carbon-intensive energy resources) will include an assessment of the reduction of carbon dioxide $\left(\mathrm{CO}_{2}\right)$, methane $\left(\mathrm{CH}_{4}\right)$, and nitrous oxide $\left(\mathrm{N}_{2} \mathrm{O}\right)$. We calculate the reduction of greenhouse gas emissions from the replacement of natural gas by biogaz in heat generating installations. If use $1 \mathrm{TJ}$ of natural gas is burned, $55350 \mathrm{~kg}$ of carbon dioxide $\left(\mathrm{CO}_{2}\right), 1 \mathrm{~kg}$ of methane $\left(\mathrm{CH}_{4}\right)$ and $0.1 \mathrm{~kg}$ of nitrous oxide $\left(\mathrm{N}_{2} \mathrm{O}\right)$ will be emitted. Utilization of natural gas in cogeneration units $413798 \mathrm{TJ}$ (or 9.8834 million tons) of natural gas GHG emissions in the amount of 11.463 million/t. Use of $1 \mathrm{TJ}$ of natural gas in cogeneration units generates 55,405 tonnes of carbon dioxide. Thus, at one plant, with a capacity of 7,000 decalitres of ethanol per day, it is possible to produce 4.07 million $\mathrm{m} 3$ of biogaz and about 8000 tonnes of ecological fertilizer during the year. The use of biogaz in the boiler-house of the plant will save 2.4 million $\mathrm{m} 3$ of natural gas per year.

The total cost of running biogaz plants at Ukrainian alcohol beverages will be $€ 6.92$ million table 4 .

Table 4. Alcohol factories that produce fuel bioethanol.

\begin{tabular}{|c|l|c|c|c|}
\hline № & \multicolumn{1}{|c|}{ Factories } & $\begin{array}{c}\text { Power, } \\
\text { (thousand dal.) }\end{array}$ & $\begin{array}{c}\text { Output of } \\
\text { the bards } \\
\text { (liter) }\end{array}$ & $\begin{array}{c}\text { Total cost of the } \\
\text { project, EUR million } \\
\text { (excl. VAT) }\end{array}$ \\
\hline 1 & Bar alcohol factory & 886 & 101890 & 1,38 \\
\hline 2 & Gaysin alcohol factory & 886 & 101890 & 1,38 \\
\hline 3 & Lochwitz alcohol factory & 1770 & 203550 & 2,76 \\
\hline 4 & Luzhansky alcohol factory & 1012 & 116380 & 1,4 \\
\hline \multicolumn{2}{c|}{ Total } & 4554 & 523710 & 6,92 \\
\hline
\end{tabular}

Source: Developed by the authors

The experiment was conducted on the installation of continuous biogaz with the volume of a reactor $4 \mathrm{~m}^{3}$ manufactured by «Kobza-Energy». The fermentation process was carried out under anaerobic conditions in the mesophilic regime at $\mathrm{t}^{\circ}=35 \pm 2^{\circ} \mathrm{C}$, the degree of filling of the reactor $80 \%$. The postalcohol bard (PSB) of the Gaysin alcohol factory was used as raw material, the chicken manure (KP) was obtained from the LLC «Vinnytsia Poultry Factory» in Ladyzhyn and cattle manure (GVRH). The composition of biogaz was determined by standard method using a gas chromatograph brand LHM-8-MD.

The purpose of the experimental studies is to justify the optimal substrate ratio to maximize biogaz yield after the alcohol bard. In the table 5 the results of the study, with the aim of increasing the $\mathrm{pH}$ level for fermentation of post-alcohol bard, it is proposed to use chicken manure, which is a favorable substrate for microorganisms and is able to maximize biogaz yield up to $118.9 \mathrm{~m}^{3} / 1 \mathrm{t}$ and increase methane content up to $68 \%$. The total biogaz output and the specific methane output are maximally ensured at the PSB/ KP/GVR ratio of 30:50:20.

Table 5. Research results

\begin{tabular}{|c|c|c|c|c|c|}
\hline \multirow{2}{*}{ № } & \multicolumn{3}{|c|}{ Material content, $(\%)$} & Biogaz output, & Methane content \\
\cline { 2 - 4 } & PSB & KP & GVR & $(1 \mathrm{t})$ & \begin{tabular}{c}
$(\%)$ \\
\hline 1.
\end{tabular} \\
\hline 2 & 55 & 30 & 71,5 & 69 \\
\hline 2. & 30 & 50 & 20 & 118,9 & 68 \\
\hline 3. & 35 & 40 & 25 & 22,7 & 55 \\
\hline 4. & 40 & 15 & 45 & 73,2 & 68 \\
\hline
\end{tabular}

Source: Developed by the authors

The reactor volume was calculated based on the capacity utilization of 200 days per year. As a result of anaerobic digestion of the grain bard in the biogaz plant, $8319.3 \mathrm{~m}^{3} /$ day of biogaz with a heat of combustion of $24.89 \mathrm{MJ} / \mathrm{m}^{3}$ can be obtained. Natural gas price for industry $7755,60 \mathrm{UAH} / 1000 \mathrm{~m}^{3}$ cost of installation of cogeneration equipment for Bar and Gaysin alcohol factory - UAH 249,85 million, Lokhvytsia alcohol factory - UAH 378,83 million, Luhansk experimental plant - 216,7 million UAH.

At the thermal power plant of the plants where the experiment was conducted, steam generators DKVR-10-23 were installed where natural gas was the working fuel. In order to evaluate 
the possibility of burning the fuel mixture in existing burners, the gas interchangeability was estimated according to the calculations [6].

The interchangeability of gases means the possibility of burning them in burners without violating the passport characteristics. The calculations showed that in the case of burning of the mixture $\mathrm{BG}: \mathrm{PG}=13 \%: 87 \%$ it is necessary to increase the pressure on the burners by $10 \%$. Based on the obtained author's results, it is possible to substantiate the economic efficiency of the post-alcohol bard recycling project at selected distilleries. table 6 .

Table 6. Economic efficiency of biogaz production at Ukrainian alcohol factories

\begin{tabular}{|l|c|c|c|c|}
\hline \multicolumn{1}{|c|}{ Indicators } & $\begin{array}{c}\text { Bar alcohol } \\
\text { factory }\end{array}$ & $\begin{array}{c}\text { Gaysin alcohol } \\
\text { factory }\end{array}$ & $\begin{array}{c}\text { Lochwitz alcohol } \\
\text { factory }\end{array}$ & $\begin{array}{c}\text { Luzhansky alcohol } \\
\text { factory }\end{array}$ \\
\hline $\begin{array}{l}\text { Volume bioreactor, at present } \\
\text { occupancy, m }\end{array}$ & 12000 & 12000 & 24000 & 14000 \\
\hline Output biogaz, millions m ${ }^{3}$ & 12,11 & 12,12 & 24,14 & 13,84 \\
\hline Need for natural gas, millions $\mathrm{m}^{3}$ & 5,3 & 5,4 & 10,6 & 6,07 \\
\hline $\begin{array}{l}\text { The optimal biogaz / natural gas } \\
\text { mixture, \% }\end{array}$ & $13 / 87$ & $13 / 87$ & $13 / 87$ & $13 / 87$ \\
\hline $\begin{array}{l}\text { Excess biogaz, millions m } \\
\text { The amount of electricity } \\
\text { produced, millions KW }\end{array}$ & 11,3 & 11,3 & 17,14 & 9,8 \\
\hline Cost of electricity sold "green tariff" & 16,95 & 16,95 & 25,7 & 14,7 \\
\hline $\begin{array}{l}\text { Saving money on natural gas } \\
\text { purchases, millions grn. }\end{array}$ & 6,28 & 38,99 & 59,11 & 33,87 \\
\hline Investment, millions grn. & 288,45 & 28,35 & 54,32 & 31,33 \\
\hline Payback period, years & 7 & 7 & 456,13 & 255,9 \\
\hline
\end{tabular}

Source: Developed by the authors

Strategic priorities for the revival of the alcohol industry should include the modernization and reorganization of all production sites of the enterprise. This is aimed at:

- reduction of production costs due to the use of secondary energy resources;

- comprehensive introduction of renewable fuel technology;

- biogaz production after the alcohol bard;

- Reducing the use of natural resources (artesian water).

Utilizing the unused capacities of the alcohol industry by converting it to bioethanol production will allow it to meet its needs and restore the work of a large number of enterprises of the alcohol industry, improve the financial situation of the alcohol industry, increase budget revenues at all levels. The main advantages of the Ukraine alcohol factory in the biofuel market are the availability of appropriate equipment, highly qualified professional staff, placement in the raw areas, well-developed infrastructure (domestic, transport), provision of the required amount of process water, considerable experience in the industry.

Conclusions. Biogaz production at the region's distilleries will have the following effect on the region's economy: increase the region's energy independence; reduce the cost of alcohol plants for energy; to improve the ecological status of water resources of the region; reduce greenhouse gas emissions; to provide livestock with protein feed.

\section{REFERENCES}

1. Журнал Пропозиція. [Електронний ресурс]. Режим доступу: http://www.propozitsiya.com/?page=149\& itemid $=2985 \&$ number $=98$

2. Інноваційні аспекти виробництва біопалива в Україні: стан, проблеми, перспективи [Електронний peсурс]. Режим доступу: http://www.nbuv.gov.ua/portal/chem_biol/nvnau/2009_142_1/09sva.pdf

3. Перспективи і проблеми виробництва біопалива в Україні [Електронний ресурс]. Режим доступу: http://www.rusnauka.com/SND/Tecnic/6_mindjuk.doc.htm

4. Розвиток біопаливного сегмента ПЕК в Україні [Електронний ресурс]. Режим доступу: http://www.db.niss.gov.ua/docs/energy/BioPal.pdf

5. Стан розвитку виробництва біопалива в Україні [Електронний ресурс]. Режим доступу: http://bioresurs.com.ua/index.php?option=com _content\&task=view\&id= 5\&Itemid=6\&exnsid=93

6. Лук'янець А. С. Особливості синтезу системи виробництва і спалювання біогазу на спиртзаводі. Сучасні технології, матеріали і конструкції в будівництві. 2018. № 2. С. 145-151.

7. [Електронний ресурс]. Режим доступу: https://glavcom.ua/vinnytsia/news/u-bershadi-na-vinnichchinigotuyutsya-vidnoviti-virobnictvo-derzhavnoji-gorilki-580398.html.

8. Офіційний сайт Державного підприємства «Укрспирт». [Електронний ресурс]. Режим доступу: http://ukrspirt.com/news/novini_pidpriemstva/strategichni-prioriteti-vidro-1-ennya-spirtovoyi-galuzi-v-kontekstizmicnennya-energetichnoyi-samodostatnosti-ukrayini.ht 